\title{
Crisis of Relationship in General Theory of Crisis
}

Doctor of economic sciences, prof.

Bohdan Andrushkiv

$\mathrm{PhD}$, associate professor Yuriy Vovk

$\mathrm{PhD}$, senior researcher Olha Pohaydak

Post graduate student Iryna Fedyshyn

Ternopil Ivan Pul'uj National Technical University

\begin{abstract}
The article deals with the actual problem of crises, their prevention and mitigation of possible negative consequences. Problems of prediction of social contradictions and crisis management relations are investigated. Possible measures for crisis phenomena organized opposition by introducing the Economic Constitution of Ukraine as a mean of regulation of economic activity in the state are reviewed.
\end{abstract}

Submitted: August, 2011 1st revision: September, 2011 Accepted: October, 2011

Keywords: crisis, crisis theory, anti crisis management, relations crisis, Economic Constitution of Ukraine.

JEL classification: H12, P2

\section{Introduction}

The concept of crisis in every sphere of public life, in engineering, biological systems has its own definition and interpretation of the phenomenon that describes the changes or some crucial stage in system's functioning. Currently, scientists studied economic crisis quite deeply and comprehensively, but some aspects of this unique process of society transformation become apparent in new types and forms. For example, in conditions of longterm and comprehensive crisis of our society new stages of its passage began to reveal. In this case, any information in the area concerning this topic and in the context of economic mechanisms improving, system relationships in economy sphere, human capital motivation are studied by practitioners.

Actually these circumstances determine not only the need for further deeper and more thorough study of the phenomena, but also the urgency and timeliness of this article.

Analyzing the social and economic situation of recent times, scientific and newspaper articles on the subject, studying the progress of the restructuring process, we have reasons to make conclusion - the theory of management is developing and expanding. Due to issues and public opinion study in this area among ordinary citizens, the Academy of Social Management found that development of production at this stage is characterized not only by well-known stages: deceleration, decline, recession and crisis, but also is defined by new terms such as: regression, degradation and collapse.

According to the results of scientific research examples of related economic crises that occurred in different states at present stage and in past centuries are given. Meanwhile, they (crises) existed long before those mentioned years. Moreover, at each stage they were unified, 
acquired new forms. Currently, there are no scientific definitions of these concepts yet, but some deterioration of social and economic situation definitely has to be understood under their meaning.

Scientific studies on this topic of Vasilenko V. (Василенко В., 2005), Ansoff I. (Ансофф И., 1989), Krutko V. (Крутько В., 1994) deserve much attention. Interregional Academy of Personnel Management has some theoretical and teaching developments in this area. The school's book "Anticrisis Management" (Чернявский A., 2000), has received wide recognition among scientists and citizens of Ukraine. There are corresponding publications on this subject of Ternopil Ivan Puluj National Technical University and Ternopil National Economic University. Recently dedicated to this problem International scientific conference had been held in Antalya (Turkey 2007), where corresponding recommendations were suggested. However, one of the first who saw the causes of economic crises in the peculiarities of reproduction of capital, was a prominent Ukrainian scientist and economist M. Tugan-Baranovsky. His work "Industrial crisis in modern England, their causes and influence on national life" (Туган-Барановский М., 2004) which was published in St. Petersburg in 1894 and subsequently translated into German (1901) and French (1913) languages, became classics of the world of science.

Porter describes the behavior of state's economy in conditions of uncertainty and instability, indicating its main causes, namely: industrial structure, the interaction between participants, competitors, information provision (Porter, 1980, p. 89-91).

Not to mention, in this regard, the Program of the Cabinet of Ministers of Ukraine of emergency measures to stabilize the economy and its disaffiliation with crisis, which is accomplished with some difficulties due to known reasons ${ }^{1}$.

Meanwhile, there are no profound scientific researches in this area yet in Ukraine. Practically the nature of crises outbrake is not investigated, scientifically based ways out of system crisis are not produced, which must be seen currently in the context of laws and regularities of the global economy functioning.

The need of Economic Constitution of Ukraine elaboration and application is reasonable and righteous because it may be a major regulatory tool of economic processes in the framework of existing legislation and that is innovative in circumstances of economic and legal analogies absence. In compliance with this constitution the functioning of national economy would ensure economic and financial vision of competitive industries perspective development with scientifically based tax potential of regions, economic protection of domestic producers and social protection of citizens.

This will lead to honest, on-time and most importantly fair distribution and redistribution of income, gross national product, creating conditions and interest in creative work, legitimate social policy realization etc. Indeed, if this doesn't happen economic crisis stagnation will lead to further economic degradation and decline of the state because of a well-known reasons. Actually the latter concerns ukrainian politicians, the public and ... science, conclusions of which are not very interesting to state administrative bodies. That is proofed by numerous critical publications in the media ${ }^{2}$.

The aim of article is to study nature and origin of peculiarities and crisis development; to introduce actions in order to mitigate its impact on social processes and life. Implementation of this plan in our state, by authors belief, is possible through elaboration and application of the Economic Constitution of Ukraine.

\footnotetext{
${ }^{1}$ The major causes of this process are: violation of economic relations and the production rate due to global crisis, and others.

${ }^{2}$ http://www1.franko.lviv.ua/adm_kamenjr/cms/?Kamenyar_No7\%2C_zhovtenmz_2009_r._Bogdan_Gavrilishin IPoganii_stan_Ukrayini_zumovlenii_tim\%2C_sho_v_nas_nemaye_nacionalmznoyi_elitiI; http://tsn.ua/analitika/orda.html
} 


\section{Characteristics of Ukraine's perspective in present global crises scale}

Ukraine's strategic goal in conditions of a cruel globalized world is to build state with stable economy, highly modern society, competitive production and proper organization of manufacturer's protection.

Practically this means not only clear articulating of national interests of Ukraine, elaboration of perfect institutional and legal mechanisms of its protection, but also conscious and consistent advocacy through anti-crisis measures application.

Currently, the social crisis is classified (by most expressive features) on economic, political (political environment), religious-spiritual (which take place in a religious environment), exchange, financial, demographic, ecological, administrative and even constitutional types. Overall, in the present context, the list can be enumerated dozens in every sphere of public life.

According to the results of scientific research we can give an examples concerning economic crisis, which occurs in different countries at the present stage and occurred in the past centuries. Moreover, they have been unified at each stage and they've been given many different interpretations. It is found that in the field of social production in post-soviet states crisis of insufficient production dominated. Abroad more often the crises of overproduction took place, which are characterized by relevant depression conditions as well. Today the roots of their origin are investigated insufficiently. So far, scientists of post-totalitarian space investigate means of their elimination but not causes of their appearance ${ }^{3}$.

It is known that in critical confrontation special lever belongs to the use of knowledge in this sphere, for directions detection of their application and effectiveness of final results providing, on which not only laws and regulations affect, but also formal, arbitrary factors, including stealth, cunning, treachery etc. Because of this, polarization of society is provoked and as a result - one its part has no possibilities for organization of business and another part successfully develop or bloom on that fertile ground.

We studied the nature of origin and consequences of relationship crisis, which demonstrated in Fig. 1 .

Actually deterioration of relations provokes further negative consequences of this phenomenon - decline of production, sales, inflation, etc. Living example in this respect is again the state of Ukraine, which became independent, and even in result of dissolution of the USSR, relationships gap, having by scientists evidence the highest potential among all counties of post-totalitarian space, immediately gained large number of various conflicts and crises. However, we realize that we live in a unique global environment, environment of permanent crisis, which no one wants to struggle with because of certain factors, hoping that all will settles itself.

\footnotetext{
${ }^{3}$ http://ukrslovo.org.ua/ukrayina/nauka-i-osvita/ukrayinska-nauka-nakazano-dobyty.html
} 


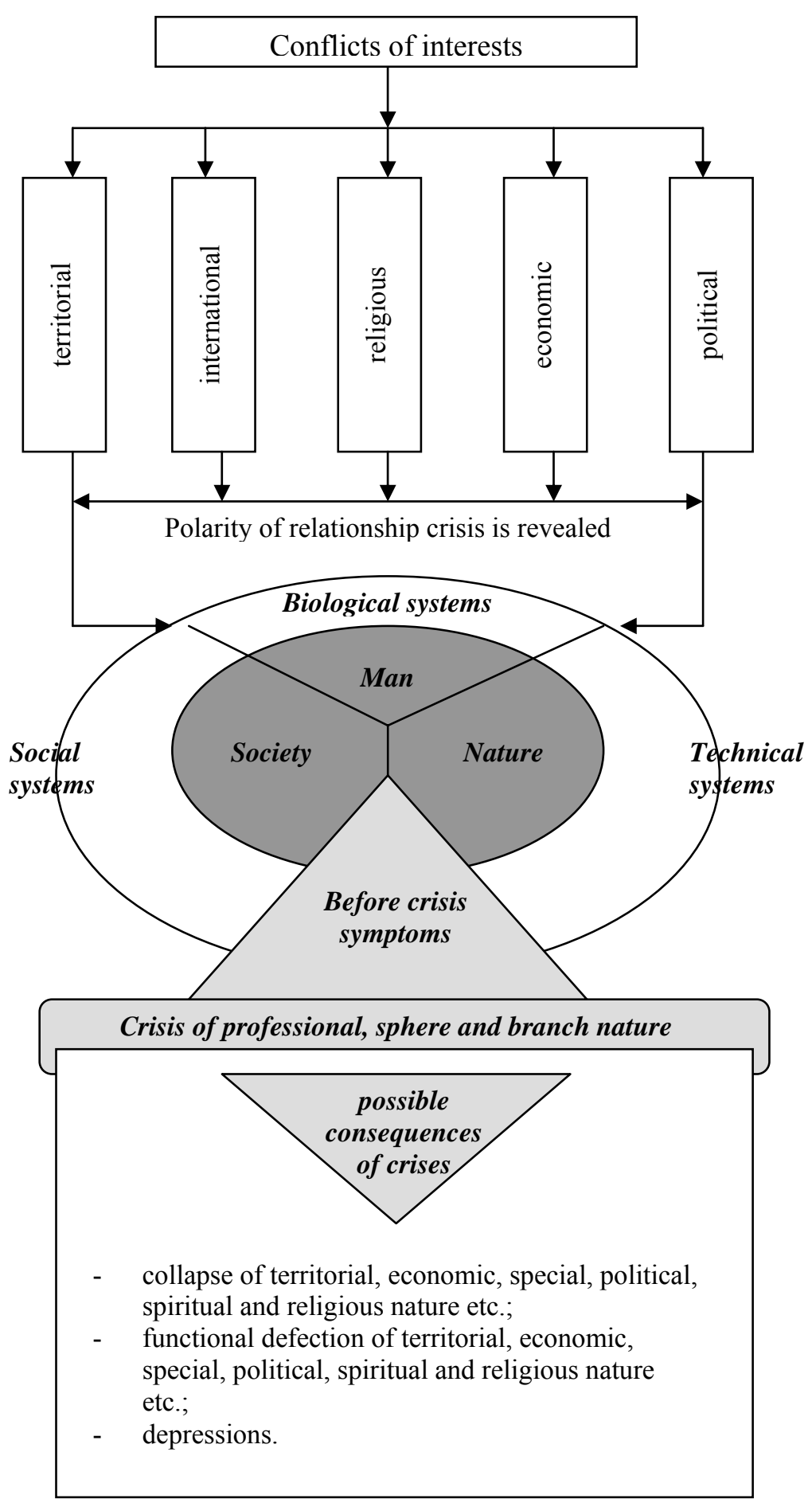

Fig. 1. The nature and consequences of relationship crisis Source: own compilation.

Actually unwillingness to solve the pressing problem of the crisis can be explained by incompetence on the one hand, and on the other hand - by scientists' and experts' disappointment because of politicized state actions of leadership, who work without strategic plan (Україна за двадцять років, 2011), and do not build clear transparent prospects.

Meanwhile in the sphere of global economic crises certain financial, monetary and other processes are adopted, which are attached to ukrainian difficulties of different spheres 
with specific indicators: increasing of tariff and price positions, decline of small business, downturn of social production, inflation, deterioration of living standards.

It is important to mention that Ukraine has economic reserve, which can multiply at least by 2-3 times state budget and improve life social standards and social protection of citizens.

Economic reserve is not only in production and sales, in taxes increasing of legal economic activity, but it is also in destruction of shadow illegal schemes allowing some oligarchic groups to avoid taxation.

It is well-known that super-profits continue to be defalcated through various shady mechanisms in all sectors of national economy. The most important means to prevent them are these:

- calculation of all customs payment, elimination of smuggling. According to preliminary data, the elimination of customs "negligence" may give significant additional revenues to budget.

- disclosure of speculations and machinations in the energy sector, destruction the myth of economic and energy "hopelessness" of Ukraine. Public understanding of Ukraine due to efforts of propaganda established the idea of alleged poverty of our country for fuel and energy resources.

In accordance with annual data of energy mining Ukraine holds 3-4 place in Europe after Russia, Norway and England (90 million tons of coal, 7 million tons of oil, 20 billion cubic meters of gas additionally supplemented with 40 billion cubic meters of gas that Russia pays for its gas transit through Ukrainian territory to Western Europe) (Саприкін, 2001). According to preliminary information, this activity can also provide additional budget revenues.

Taxation of extra profits of large corporations, individuals, luxury goods (expensive cars, jewellery, large and excess property) may also increase revenue.

Meanwhile economic policy generally requires significant adjustments with complete re-orientation on full regional economic calculation that can enable regions to demonstrate creative initiative.

Due to mentioned above factors state and local budgets can additionally receive significant revenues under current revenue budget.

The data reflect only the conventional picture of possible revenue increase to state budget, which can not only alleviate the crisis strikes, but also to accumulate resources for effective reform. Shifts can be attained by mean of introduction of the Economic Constitution of Ukraine, which involves not only regulation but also the responsibility and these can change and enhance the international image of Ukraine.

Ukrainian foreign policy at present, in our opinion, is in formative stage and among its main goals is admission into the world community as an equal partner. Only strong selfsufficient national economies can participate in global integration projects.

Objective processes of interstate cooperation can be used for the benefit of native nation. Therefore, on our belief, constructive neighbourhood program with Russia, designed for 5-10 years must be suggested, with simultaneously accelerated integration into the EU, which can expand the list of orders for high-technology products, new technologies, resources of energy etc.

Using the revealed regularities in the system of crisis in the context of globalization, in order to ensure purposeful influence on these processes in a planetary scale, the international community should today, immediately mobilize efforts to develop norms of mutual relations in all spheres of social coexistence. This will allow to regulate, from the moral and humanistic position, international relations not only in trade sphere, as it is between individual nations today, but also in religious, spiritual and other forms of social life. 
Conceptual functioning foundations of mentioned International commission for problems of relations settlement is presented in Fig. 2.

We developed the principle of: "Establishment of constructive relations in the precrisis period toward consistent and logical reduction of possible negative effects and their smooth transfer into track of improving relations and reforms inculcation, depending on the areas of social activity" and the time has come to implement it. This thesis may get some formula expression, for example:

$$
\mathrm{PCRO}+\mathrm{PCF}+\mathrm{LOF} \ldots . .=\mathrm{SFS}
$$

where PCRO - predicting of possible contradictions in constructive relationships organization;

PCF - production of influence mechanisms on crisis-making factors;

LOF - localization of other negative factors;

SFS - stable functioning of society or spheres of public life.

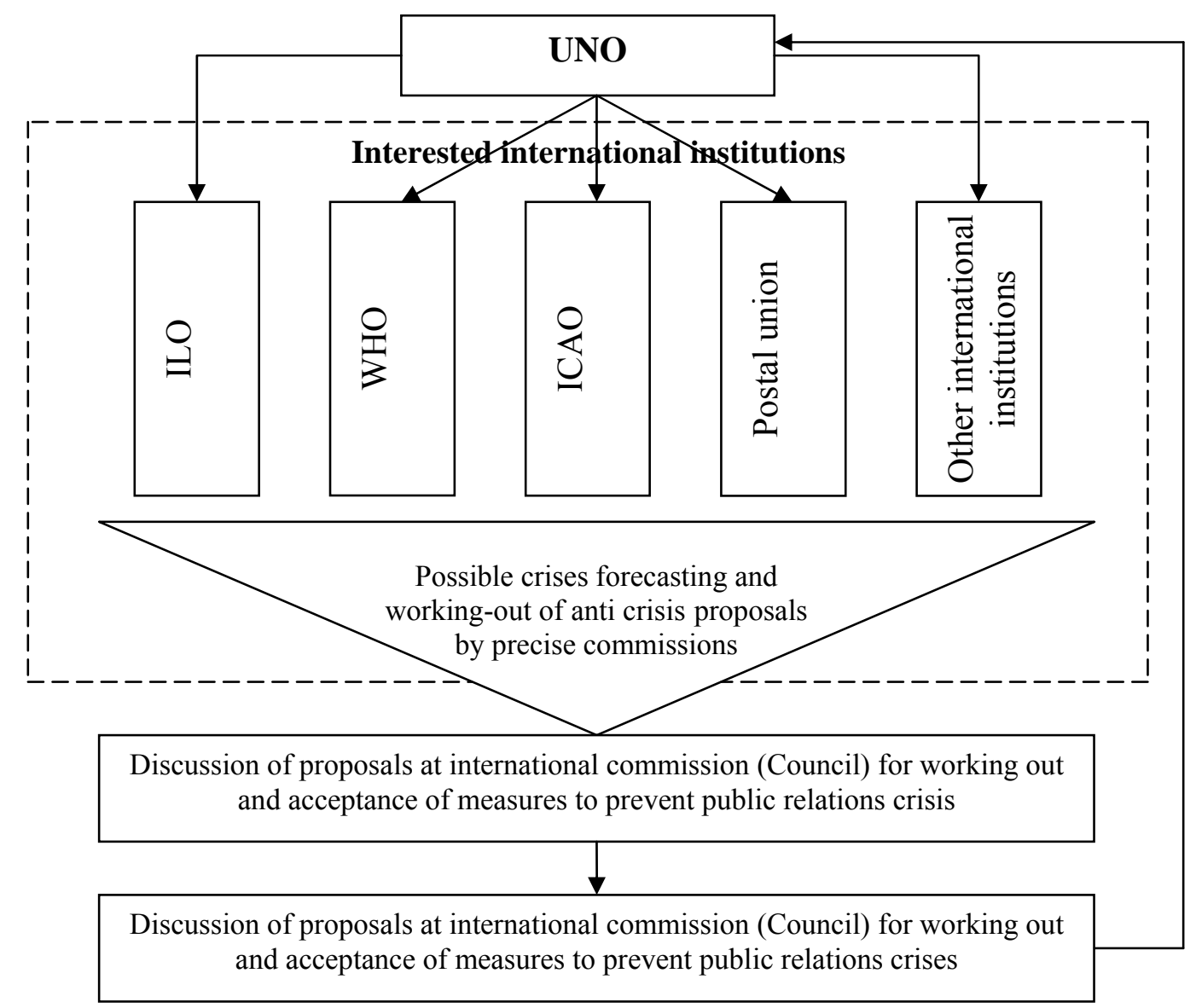

Fig. 2. Conceptual functioning foundations of international commission on crisis regulating relations

Source: own compilation.

Prediction stages of possible contradictions and relationships crisis management organization presented in Fig. 3.

People say: "Everything new is well forgotten old". In today's conditions of communication provision moments are presented to fulfil suggested developments fully.

International institutions under the auspices of the UN should unite and form 
international commission (Council) on this issue and begin to develop specific organizational measures to solve them in civilized, peaceful way.

1. Detection of pre-crisis situations, possible contradictions of interests and their nature forecasting

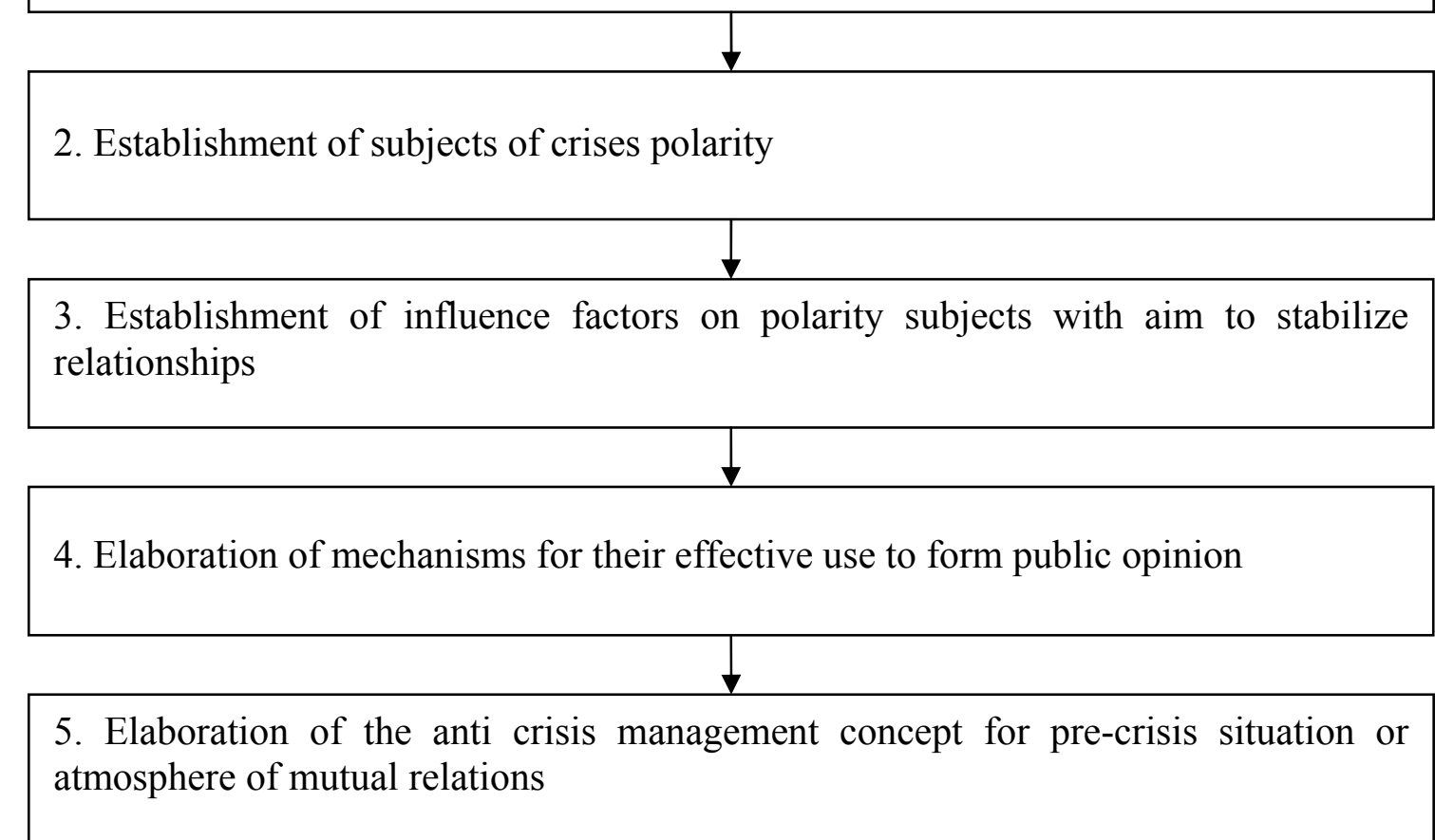

Fig. 3. Stages of crisis relations management

Source: own compilation.

According to scientists during planet's existence there were about 50 thousand small and big wars which were the result of one or another crisis that preceded them. It is impossible to name the number of victims and material damage that occurred as a result of wars during this time. There's no need to print the numbers that are measurements in different monetary units with varying their value.

The reason for their origin in most cases was actually first deterioration of relations at international level, in each case, whether religious or economic, territorial or national, which then led to multiplication of all subsequent crises, including general social. Confirmation of above mentioned is a rupture and destruction of relationships that were formed over 70 years in former USSR. Without a doubt, the crisis of relations, which underlies all crises, have been generating these negative phenomena. Meanwhile, sphere activity regulation can play the most important role to prevent them.

Economic Constitution of Ukraine can perform this function in economics. These and other circumstances require its elaboration and implementation. This document, based on economic laws, will regulate economic activity of Ukraine. Thus conditions are created for prevention of crisis processes and ensuring sustainable national and economy development, political peace in Ukraine, the growth of international authority of Ukraine among global community, creation of favourable climate for attracting foreign investments into national economy. 


\section{Conclusion}

Crises occur usually in the presence of certain conflicts and contradictions that is to say with the presence of bipolar crisis making factors. For example, the contradictions between nature and man, nature and state generate ecological crisis and consequently its corresponding positive or negative results. Conflict situations of system, household or other nature, between men and women can affect all sides of social life and provoke certain demographic shifts. Conflicts between state and private parties can cause political crises. In Ukraine, as it has been noted, numerous economic crises, recessions and depressions, including regression, degradation, collapse become most apparent.

Thus in accordance with existing theory of crisis elaboration and introduction of fundamentally new Ukraine's political ideology at the present time is expedient, based on centuries-deep roots of the Ukrainian nation, ukrainian idea of freedom and justice, based on worked out in the modern world most advanced management mechanisms of XXI century society development, which in economic sphere can be secured in the Economic Constitution of Ukraine.

\section{References}

Ансофф, И. (1989), Стратегическое управление, Экономика, Москва, 1989.

Василенко, В. О. (2005), Антикризове управління підприємством: Навч. посібник, Вид. 2-ге, виправл. і доп., Центр навчальної літератури, Київ, 504 р.

Гаврилишин, Б. (2009), Поганий стан Украӥни зумовлений тим, щз в нас немає національної еліти, viewed 2009, $<$ http://www1.franko.lviv.ua/adm_kamenjr/cms/?Kamenyar_No7\%2C_zhovtenmz_200 9_r._Bogdan_Gavrilishin_IPoganii_stan_Ukrayini_zumovlenii_tim\% $\% \overline{2}$ C_sho_v_nas_ nemaye_nacionalmznoyi_elitil $>$.

Крутько, В. (1994), Введение в менеджмент кризисных ситуаций: Практические рекомендации, МЗУУП, 52 р.

Саприкін, В. (2001), Енергетика України: економічний, політичний та стратегічний вимір, $\quad$ viewed $14 \quad$ November $<$ http://www.uceps.org/ukr/article.php?news_id=164>.

Туган-Барановский, М. Н. (2004), Промылиленныле кризисы. Очерк из сочуиальной истории Англии, Наукова думка, Київ, 368 р.

Чернявский, А. Д. (2000), Антикризисное управление. Учебное пособие, МАУП, Киев, $208 \mathrm{p}$.

Україна за двадиять років (Стан ідентичності $i$ політика пам'яті. Експерти в Чернігові - про двадиять років незалежності) / День 9 вересня 2011 р.

Українська наука: наказано добити?, viewed 9 August 2011, $<$ http://ukrslovo.org.ua/ukrayina/nauka-i-osvita/ukrayinska-nauka-nakazanodobyty.html>.

Michael E., Porter (1998), Competitive strategy: Techniques for analyzing industries and competitors, The Free Press Adition, 396 p. 